\title{
EARLY CHANGES IN THE TRANSITION FROM CONVENTIONAL TO NO-TILLAGE IN A VOLCANIC SOIL CULTIVATED WITH BEANS
} (Phaseolus vulgaris L.)

\section{CAMBIOS TEMPRANOS EN LA TRANSICION DE LABRANZA CONVENCIONAL A SIEMBRA DIRECTA EN UN SUELO VOLCÁNICO CULTIVADO CON FRÉJOL (Phaseolus vulgaris L.)}

\author{
Fabián Montesdeoca ${ }^{1,2 *}$, María Ávila ${ }^{1,2}$, Janeth Quishpe ${ }^{1}$, Fernando Borie ${ }^{2,3}$, Pablo Cornejo ${ }^{2}$, Paula \\ Aguilera $^{2}$, Soraya Alvarado ${ }^{1}$, José Espinosa ${ }^{1}$ \\ ${ }^{1}$ Universidad Central del Ecuador, Av. América, CiudadelaUniversitaria, Quito, Ecuador. \\ 2 Universidad de La Frontera, Av. Francisco Salazar 01145, Temuco, Chile \\ ${ }^{3}$ Universidad Católica de Temuco, Av. Manuel Montt 56, Temuco, Chile \\ *Corresponding author: fmontesdeoca@uce.edu.ec
}

\begin{abstract}
Conventional tillage (CT) is a soil management system commonly used by small farmers in the Ecuadorian highlands; they remove the soil during seedbed preparation to eliminate weeds, improve soil aeration, avoid compaction, and develop adequate rooting space. CT causes changes in physical, chemical, and biological soil properties but, in the long run, have negative effects on crop performance. Most of these effects can be avoided by using no-tillage (NT). The objective of this study was to determine the initial effects of NT, different fertilization rates and depth levels of sampling on yield and soil chemical and physical properties after the first crop cycle (prior to crop rotation scheme). A long-term field experiment was established to study the soil changes derived from the transition from CT to NT systems in a volcanic soil of the Ecuadorian highlands cultivated with the following crop rotation schemes: beans (Phaseolus vulgaris L.)-corn (Zea mays L.)-beans and beans-amaranth (Amaranthus caudatus L.)-beans. The results for the first crop cycle show that bean yield was $42 \%$ higher under NT compared to $C T$, indicating that the soil improvements promoted by NT had effects on crop yield; however, only the changes in $\mathrm{pH}$ and water storage capacity presented significant differences, levels of soil organic matter, total $\mathbf{N}$, available $\mathbf{P}$, and bulk density showed a trend towards improvements under NT. This suggests that NT allows for increased crop yield and improved crop rotation performance in the medium and long term.
\end{abstract}

Key words: Ecuadorian highlands, tillage, beans, crop rotation.

\section{RESUMEN}

La labranza convencional (CT) es una práctica agrícola ampliamente usada por los pequeños agricultores de la sierra del Ecuador. En la operación de labrado, se remueve suelo durante la preparación de la cama de siembra, para eliminar malezas, mejorar la aireación, evitar compactación y desarrollar un adecuado ambiente para el crecimiento radicular. Esta remoción causa cambios en las propiedades físicas, químicas y biológicas del suelo, que con el tiempo tienen efectos negativos en los cultivos. Muchos de estos efectos se pueden evitar usando siembra directa (NT). El objetivo de este estudio fue determinar los efectos iniciales de la siembra directa, diferentes tasas de 
fertilización y niveles de profundidad del muestreo sobre el rendimiento y las propiedades químicas y físicas del suelo después del primer ciclo de cultivo. Se implementó un experimento a largo plazo para determinar los cambios promovidos por la transición de labranza convencional (CT) a siembra directa (NT) en un suelo volcánico de la sierra del Ecuador cultivado bajo dos esquemas de rotación: fréjol (Phaseolus vulgaris L.)-maíz (Zea mays L.)-fréjol y fréjol-amaranto (Amaranthus caudatus L.)fréjol. Los resultados correspondientes al primer ciclo de cultivo indican que el rendimiento del fréjol fue $42 \%$ más alto con la siembra directa, sugiriendo que los cambios en el suelo promovidos por este sistema de labranza tienen efecto en el rendimiento del cultivo. A pesar de que solamente fueron significativos los cambios en $\mathrm{pH}$ y contenido de capacidad de almacenamiento de agua, los resultados sobre materia orgánica del suelo, nitrógeno total, $\mathrm{P}$ disponible $\mathrm{y}$ densidad aparente muestran una tendencia de mejoramiento con la siembra directa, lo que sugiere que esta práctica mejora el rendimiento inicial y promovería un mejor comportamiento de las rotaciones a mediano y largo plazo.

Palabras clave: Sierra de Ecuador, labranza, fréjol, rotación de cultivos.

\section{INTRODUCTION}

Ecuador is crossed by the Andes mountain range, which divides the country in three natural continental regions: the Coastal plain, Highlands, and Amazonia. The Highlands inter Andean basins, which are narrow and long depressions (1.4 million ha) at an altitude from 1600 to 3000 meters, are suitable for growing a wide range of temperate climate crops (Moreno et al., 2018). Spaces devoted to agriculture have a rugged topography that is not suited for intensive farming. Furthermore, land tenure is characterized by a high percentage of small productive units of less than 5 ha, which are exposed to intensive land use. Soils remain uncovered and subject to erosion because farmers use crop stubble to feed livestock, and also lack knowledge on farming systems without soil removal (Espinosa and Moreno, 2018).

No-tillage (NT) is one of the soil conservation practices that effectively controls soil erosion, with other widely recognized beneficial effects (Khan et al., 2017). There is scarce published information on the use of no-till farming in Ecuador, but the studies conducted during the past few years indicate there is a tendency towards improved yields with NT in volcanic highland soils. In general, only one crop cycle has been reported, but the effects of NT on soil properties with respect to conventional tillage (CT) were partially described (Alvarado et al., 2011).

It has been reported that NT and crop rotations are complementary to maintain medium and long-term soil quality (Munkholm et al., 2013). However, at national level, there is not enough information on the contribution of crop rotations, particularly in small farms. Then, it is important to document the effects of NT and rotation schemes on soil properties and carbon dynamics, which is especially relevant in the framework of the current global climate change.

The objective of this study was to determine the initial effects of NT, different fertilization rates and depth levels of sampling on yield and selected soil chemical and physical properties after the first crop cycle under two common rotation schemes.

\section{MATERIALS AND METHODS}

\section{Experimental site}

This study was conducted at the Experimental and Teaching Farm La Tola, Universidad Central del Ecuador, located at La Morita, Pichincha province. The site is located at $78^{\circ} 21^{\prime} 18^{\prime \prime} \mathrm{W}$ and $00^{\circ} 13^{\prime} 49^{\prime \prime} \mathrm{S}$, with an altitude of 2505 m.a.s.l., a mean annual rainfall of $868 \mathrm{~mm}$, a temperature of $17^{\circ} \mathrm{C}$ and relative humidity of $73.9 \%$. The soil is a Mollisol of volcanic origin classified as Entic Durustolls of sandy loam texture, $\mathrm{pH}-\mathrm{H}_{2} \mathrm{O}$ 6.9 , organic carbon (OC) $1.89 \%$, total nitrogen (TN) $0.22 \%$, available-P (Olsen) $140 \mathrm{mg} \mathrm{kg}^{-1}$, exchangeable $\mathrm{K}^{+} 1.27 \mathrm{cmol} \mathrm{kg}^{-1}, \mathrm{Mg}^{2+} 5.12 \mathrm{cmol} \mathrm{kg}^{-1}$, and $\mathrm{Ca}^{2+} 9.5 \mathrm{cmol} \mathrm{kg}^{-1}$. Two rotation schemes were implemented under NT and CT: common beanmaize and common bean-amaranth. Common bean was used because of its $\mathrm{N}$ contribution to the second crop.

The experimental design was a complete random block design in a split plot arrangement with eight replications. The experimental site was previously planted with oats to homogenize soil fertility, and residues were discarded. After a 3-month fallow period, oat regrowth and weeds were treated with glyphosate herbicide. Tillage systems (CT and NT) were the main plot and the subplots were the treatments based on the following fertilizer rates: $\mathrm{N}_{1}, \mathrm{~N}_{2}$ and $\mathrm{N}_{3}$, with 11, 22 , and $33 \mathrm{~kg} \mathrm{~N}$ ha $^{-1}$ as urea, and $\mathrm{P}_{1}, \mathrm{P}_{2}$, and $\mathrm{P}_{3}$, with 22,44 , and $66 \mathrm{~kg} \mathrm{P} \mathrm{ha}^{-1}$ as Triple Superphosphate, respectively. A control plot with no fertilizer application was also included. 
Plots under NT were treated with herbicide to control weeds avoiding soil movement. All plots were manually planted under the same agronomic management throughout the growing season. Experimental plots were sown with common bean in the middle of the rainy season and fertilizer rates were applied 21 days after planting. The seed rate used was $90 \mathrm{~kg} \mathrm{ha}^{-1}$ in plots of $12 \times 7 \mathrm{~m}\left(84 \mathrm{~m}^{2}\right)$, spaced at $0.70 \mathrm{~m}$ between planting rows and $0.30 \mathrm{~m}$ between planting sites. Beans were harvested at maturity after 4 months growing cycle. Soil sampling and analysis were performed immediately after harvest.

For the second cycle, the large plots of NT and $\mathrm{CT}$ were divided into two subplots. For each plot, one subplot was sown with Corn (C) and the other with Amaranth (A) using four fertilization rates and three repetitions. So two rotation schemes were established: the first was beans-corn-beans and the second beans-amaranth-beans. The results presented in this article correspond to the first crop cycle.

Measurements. After harvest, bean grain were classified, cleaned, and dried at $12 \%$ moisture. The harvested grain were weighed and expressed in $\mathrm{kg} \mathrm{ha}^{-1}$. Measured soil properties were as follows: bulk density (Blake, 1976); water storage capacity (Gardner, 1976), soil $\mathrm{pH}-\mathrm{H}_{2} \mathrm{O}$ (Peech, 1979); total nitrogen (TN) (Bremner, 1979); phosphorus (P) Olsen (Sims, 2000); potassium
(K), calcium (Ca) and magnesium (Mg) (Heald, 1979; Pratt, 1979). soil organic matter (SOM) was calculated using the soil organic carbon (SOC) procedure proposed by Allison (1979) using 1.892 as conversion factor.

Statistics. The factorial ANOVA analysis and mean comparison (DMS 0.05 and post hoc multiple range test of Tukey) were conducted using Infostat (Di Rienzo et al., 2018). The ANOVA was used for each of the proposed sampling depths. Soil core samples were taken at two sampling depths $(0-5$ and $5-20 \mathrm{~cm})$.

\section{RESULTS AND DISCUSSION}

\section{Effects of tillage systems and fertilizer rates on} bean yields

There were significant differences in grain yield and 100-seed weight between CT and NT at all fertilizer rates (Table 1). In fact, yield was higher under NT than CT, suggesting that no soil disturbance improves the general conditions for crop growth. Previous studies on the effect of the transition from CT to NT on yield indicate that NT results in higher production or at least equal to that of CT (Derpsch et al., 2010). These results indicate that there is potential for the successful production of dry beans using NT. There is no information on the effect of tillage disturbance on bean yields in the Highlands of Ecuador, but

Table 1. Grain yield of common beans (Phaseolus vulgaris L.) cultivated in a volcanic Mollisol under two contrasting tillage systems at four different fertilizer rates.

\begin{tabular}{|c|c|c|c|}
\hline Tillage system & Fertilizer rates & $\begin{array}{c}\text { Yield } \\
\left(\text { kg ha-1) }^{-1}\right)\end{array}$ & $\begin{array}{l}\text { 100-seed weight } \\
\text { (g) }\end{array}$ \\
\hline \multirow{4}{*}{$\mathrm{NT}^{1}$} & $\mathrm{~N}_{0} \mathrm{P}_{0}$ & $2518.7 \mathrm{a}$ & $56.6 \mathrm{a}$ \\
\hline & $\mathrm{N}_{1} \mathrm{P}_{1}$ & $2464.5 \mathrm{ab}$ & $56.5 \mathrm{a}$ \\
\hline & $\mathrm{N}_{2} \mathrm{P}_{2}$ & 2559.9 a & $57.2 \mathrm{a}$ \\
\hline & $\mathrm{N}_{3} \mathrm{P}_{3}$ & $2547.2 \mathrm{a}$ & $57.7 \mathrm{a}$ \\
\hline \multirow{4}{*}{ CT } & $\mathrm{N}_{0} \mathrm{P}_{0}$ & $2028.4 \mathrm{bc}$ & $50.1 \mathrm{c}$ \\
\hline & $\mathrm{N}_{1} \mathrm{P}_{1}$ & $1524.5 \mathrm{~d}$ & $51.2 \mathrm{bc}$ \\
\hline & $\mathrm{N}_{2} \mathrm{P}_{2}$ & $1753.4 \mathrm{~cd}$ & $52.1 \mathrm{bc}$ \\
\hline & $\mathrm{N}_{3} \mathrm{P}_{3}$ & $1786.4 \mathrm{~cd}$ & $52.7 \mathrm{~b}$ \\
\hline \multicolumn{4}{|l|}{ ANOVA } \\
\hline Tillage & & $31.27^{* * *}$ & $84.74^{* * *}$ \\
\hline Fertilization & & 0.74 & $1.97 \mathrm{~ns}$ \\
\hline Tillage*Fertilization & & $0.49 \mathrm{~ns}$ & $0.35 \mathrm{~ns}$ \\
\hline \multicolumn{4}{|c|}{$\begin{array}{l}{ }^{1} \mathrm{NT}=\text { No-tillage; } \mathrm{CT}=\text { Conventional tillage } \\
{ }^{*} \mathrm{p}<0.05 ;{ }^{* *} \mathrm{p}<0.01 ;{ }^{* * *} \mathrm{p}<0.001 \text {. } \\
\text { Different letters in a column indicate statistical differences according to Tukey's multiple } \\
\text { range test at } \mathrm{p}<0.05 \text {. }\end{array}$} \\
\hline
\end{tabular}


land degradation has been identified as one of the problems in this area (Espinosa and Moreno, 2018). However, recent experiments have reported that NT yields of different crops are as high as, or higher than, those obtained under CT (Alvarado et al., 2011; Quichimbo et al., 2012; Gallager et al., 2017). The study conducted by Alvarado et al. (2011) with open pollinated corn for human consumption, which is common in the Highlands of Ecuador, reported a grain yield of $5.2 \mathrm{t} \mathrm{ha}^{-1}$ for NT and 4.3 for CT.

The higher yields obtained in the check plot $\left(\mathrm{N}_{0} \mathrm{P}_{0}\right)$ with NT and $\mathrm{CT}$, could be due to the effect of the experimental site conditions prior to our experiment. Despite the actions taken to level soil fertility, there might be some persistence from different potato fertilization experiments conducted for certain period of time.

\section{Effects of tillage systems and fertilizer rates on soil physical characteristics}

Although the long-term effects of conservation tillage on crop yield have been extensively described (Derpsch et al., 2010), there is limited information regarding tillage-induced changes on soil properties in the first years of transition from CT to NT. The use of both tillage systems might result in soils having different soil physical and chemical properties, since the soil matrix undergoes less disturbance and such differences can be greater with time under NT (Blanco Canqui, 2012; Lal, 2015). However, changes in soil physical properties are expected to develop slowly after the initiation of NT (de Moraes et al., 2015).

In this study, changes in bulk density and water storage capacity were evaluated at two soil layers, 0-5 and 5-20 cm from the soil surface. Data analysis (Table 2) shows that the beneficial effects of NT on these soil physical characteristics are more noticeable in the $0-5 \mathrm{~cm}$ layer than in the deeper layer. As plowing involves the breaking of soil aggregates, changing soil structure and promoting SOM losses by $\mathrm{C}$ mineralization due to rootlets and fungal hyphae crushing, lower densities are expected in undisturbed soils (Blanco-Canqui et al., 2009; Wingeyer et al., 2015). Bulk density is usually highly correlated with clay content and tillage in the upper soil layer (Bronick and Lal, 2005; Alvarez et al., 2009), and NT helps to reduce soil compaction (Singh et al., 2014). In our study (in a volcanic Mollisol), the effect of tillage on bulk density showed no statistical significance $\left(1.34\right.$ and $1.39 \mathrm{~g} \mathrm{~cm}^{-3}$ for NT and CT, respectively) at the $0-5 \mathrm{~cm}$ soil layer, while the same trend was observed at the $5-20 \mathrm{~cm}$ layer (Table 2). However, the literature contains conflicting information regarding the effect of
NT on bulk density. Data collected by Li et al. (2007) in a Cambisol from China, with a wheat monoculture for 15 years, showed a higher bulk density in NT plots during the first six years probably due to tractor traffic. Furthermore, an experiment conducted by Roldan et al. (2007) in a high clay Vertisol from Mexico in a maize-bean rotation recorded a higher bulk density under NT compared with that obtained under CT at the end of a four-year period. In addition, these authors reported higher values of soil macroaggregates in NT soils at 0-20 depth. In the present study, the interaction of tillage and fertilizer rates on bulk density was highly significant $(p<0.01)$ at both sampling depths (Table 2). This suggests a synergism of these two factors in the performance of bulk density as an indirect effect of fertilizer application on SOM accumulation promoted by increased root biomass (Sainju et al., 2005).

Water storage capacity is of great importance in soil fertility because it is useful to describe water availability and usually predicts its incidence on plant root growth and crop production (Morison et al., 2008). The increment of SOM promoted by NT also increases soil macroaggregates, soil aeration and the number of small channels that are filled with water and dissolved nutrients, affecting plant growth and soil root ability and workability (Dexter, 2004). In the present study, water storage capacity was higher under NT compared to CT at both depths, particularly in the upper layer (Table 2). The greater water storage capacity observed in NT beans (20.01\%) compared to that in CT $(15.57 \%)$ can be explained by the protective effect produced by plant residues on the soil surface; such residue accumulation also prevents soil exposure to sunlight and wind, promoting a greater water storage capacity for the crop (Vidal et al., 2002; Crovetto, 2006). The changes in water storage capacity values for NT and CT were not significant at the $5-20 \mathrm{~cm}$ soil layer, but the interaction tillage and fertilizer rates were highly significant $(\mathrm{p}<0.01)$, suggesting again a tight synergism between these two factors. When comparing the effects of NT and CT on bulk density and water storage capacity content, it is observed that these two parameters are negatively correlated, showing that plots with lower density have higher gravimetric water content (- 0.04 ns). The data obtained also show that the NT treatment with the highest $\mathrm{N}$ and $\mathrm{P}$ fertilization $\left(\mathrm{N}_{3} \mathrm{P}_{3}\right)$ presents a lower bulk density value $(1.31$ $\left.\mathrm{g} \mathrm{cm}^{-3}\right)$ and a higher water storage capacity (22.17 $\%)$ than the CT- $\mathrm{N}_{3} \mathrm{P}_{3}$ treatment, with values of $1.41 \mathrm{~g} \mathrm{~cm}^{-3}$ and $15.29 \%$, respectively; however, no statistical differences were observed. This trend has been well documented in other research sites (Khan et al., 2017; Tormena et al., 2017). 


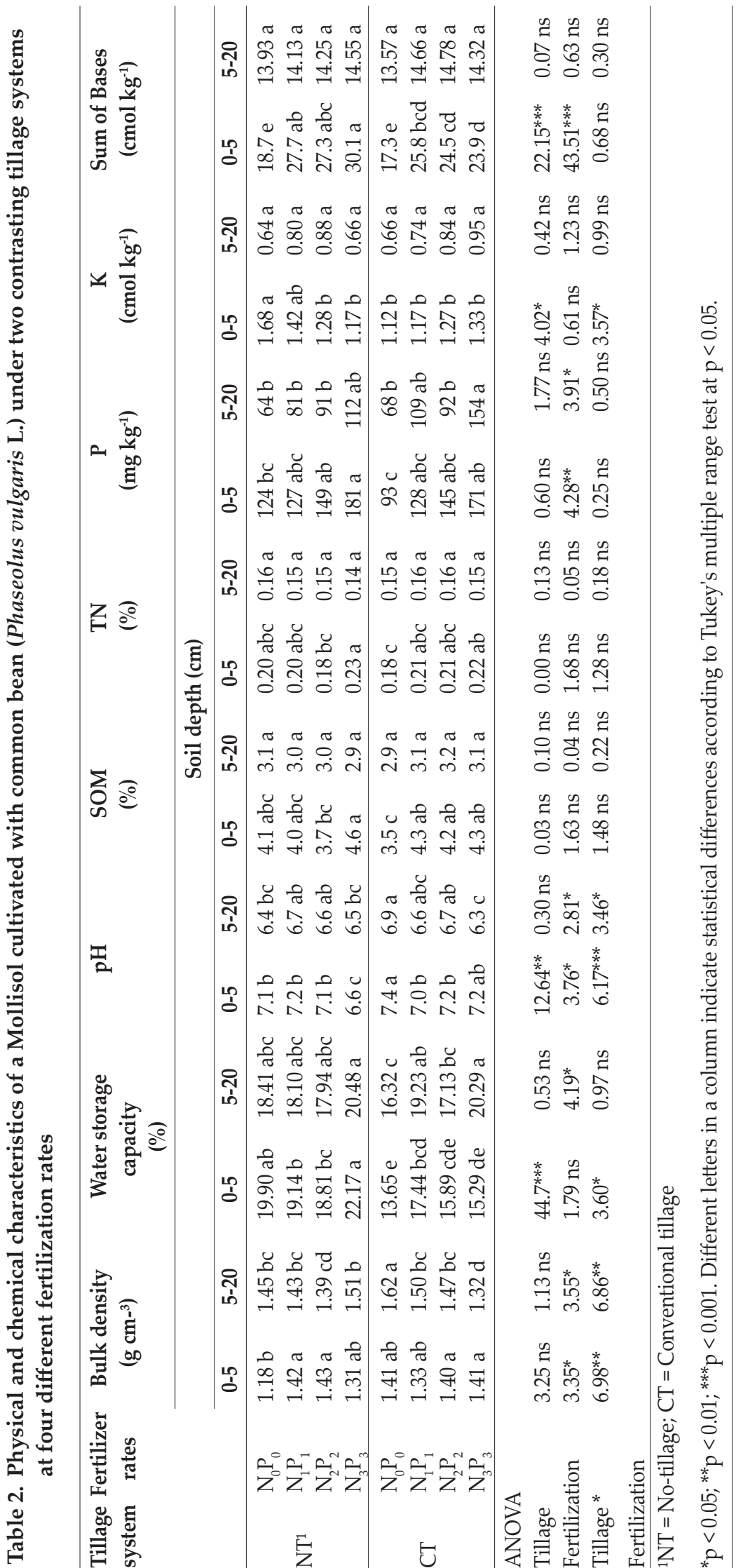


Effects of tillage systems and fertilizer rates on soil chemical characteristics

Changes in the main soil chemical characteristics due to tillage and fertilizer rate were more evident at $0-5 \mathrm{~cm}$ compared to 5-20 $\mathrm{cm}$ depth layer. Soil $\mathrm{pH}$ in the control plot was significantly lower for NT compared to CT at both depths; such differences were higher at 5-20 cm depth (Table 2). It has been reported that $\mathrm{pH}$ tends to be lower in NT compared to CT, probably due to plant detritus accumulation and decomposition in the soil upper few centimeters, which enhances microbial biomass activity, increasing $\mathrm{C}$ and $\mathrm{N}$ mineralization, producing phenolic organic acids and promoting changes in soil chemical characteristics, including soil $\mathrm{pH}$ (Balota et al., 2004; Rahman et al., 2008).

Soil management, particularly the application of ammoniacal $\mathrm{N}$ fertilizers, can produce acidification that can lead to negative soil conditions for crop growth (Bloom and Skyllberg, 2012; Havlin et al., 2014). Initially the N content of the original plant materials along with urea hydrolysis cause a $\mathrm{pH}$ increase associated with the formation of ammonium carbonate, but protons are further released by nitrification processes, producing a moderate soil acidification. It is important to note that such changes in $\mathrm{pH}$ are small and tend to modify the acidity towards values close to neutrality due to MOS buffer capacity. In this sense, a better $\mathrm{pH}$ buffering condition is expected under NT due to higher SOM content (Singh et al., 2014; Jat et al., 2019). However, these changes usually require more than one crop cycle to be evident (Díaz-Zorita et al., 2004). The main effect of fertilizer rates on soil $\mathrm{pH}$ was significant $(\mathrm{p}<0.05)$ at both sampling depths, suggesting a trend of acidification with increasing $\mathrm{N}$ fertilization.

As it was expected, at this point in the experiment (first cycle), the effects of tillage and fertilizer rate application on SOM and TN were not statistically significant (Table 2), but small differences were more noticeable in the upper soil layer. The SOM build up is quantitatively more evident only when consecutive cycles of NT and crop rotation are applied (Blanco-Moure et al., 2011; Basanta et al., 2012).

On the other hand, initial soil available $\mathrm{P}$ at the beginning of this experiment was 140 mg $\mathrm{kg}^{-1}$, but values recorded after harvest decreased to 124 and $93 \mathrm{mg} \mathrm{P} \mathrm{kg}^{-1}$ in the NT and CT control plots, respectively, suggesting that $\mathrm{P}$ use efficiency was higher under NT than $\mathrm{CT}$, based on the higher yields and lower soil $\mathrm{P}$ consumption observed in the NT control plot. The same behavior was observed with $\mathrm{K}$. There was no significant difference for the main effect of tillage but differences in soil $\mathrm{P}$ promoted by the fertilizer application were highly significant $(\mathrm{p}<$ 0.01 ) under both tillage systems, with a constant $P$ buildup in the $0-5 \mathrm{~cm}$ soil layer. However, an important and significant decrease in $\mathrm{P}$ concentration was observed at $5-20 \mathrm{~cm}$ soil layer $(\mathrm{p}<0.05)$. The lack of soil movement with the consequent residue accumulation on the surface of NT soils, as well as the low P mobility, promote the stratification of plant nutrients, particularly $P$, resulting in $P$ accumulation in the $0-5 \mathrm{~cm}$ soil layer, which gradually decreases with soil depth (Lupwayi et al., 2006; Grove et al., 2007).

The differences in the main effect of tillage on soil $\mathrm{K}$ and sum of cations $(\mathrm{K}, \mathrm{Ca}$ and $\mathrm{Mg}$ ) were statistically significant $(\mathrm{p}<0.05)$ in the $0-5 \mathrm{~cm}$ soil layer suggesting again that there is a trend of nutrient accumulation in NT plots (Table 2) rather than in CT plots.

The lack of expected SOM accumulation in NT over CT is probably due to the fact that the crop initiating the rotation scheme is a legume with a low $\mathrm{C} / \mathrm{N}$ ratio, which favors residue mineralization, thus delaying organic carbon accumulation in the soil profile (Zotarelli et al., 2012; Raphael et al., 2016).

The correlation for interdependency of the principal components presented in Fig. 1 discriminates the effects of NT and CT and suggests that there is a strong association among total grain yield and weight of 100 grains is strongly associated with bulk density, gravimetric water content, soil $\mathrm{P}$ and fertilizer rates in the NT system. The data obtained indicate that NT provides better soil conditions for bean yields.

The clustering analysis of the data in Fig. 2 provides an insight over the impact of the measured variables on bean yield. Clustering collected the NT- $\mathrm{N}_{2} \mathrm{P}_{2} 100$ and $\mathrm{NT}-\mathrm{N}_{3} \mathrm{P}_{3} 150$ treatments as one main group and CT- $\mathrm{N}_{2} \mathrm{P}_{2} 100$ and $\mathrm{CT}-\mathrm{N}_{3} \mathrm{P}_{3} 150$ as a different group, suggesting that NT soil conditions provide a better ambient for yield response to fertilizer application.

This study complements biological results recently obtained by Avila-Salem et al. (2020) in the same soils and allows concluding that, at this initial point in the transition from CT to NT, common bean yields are higher for NT. This represents an important technical argument for promoting farmer adoption of this conservation tillage system in the Highlands of Ecuador.

\section{CONCLUSIONS}

The yield of common bean, which was the initial crop prior to long-term rotation schemes, was significantly higher under no tillage (NT) 


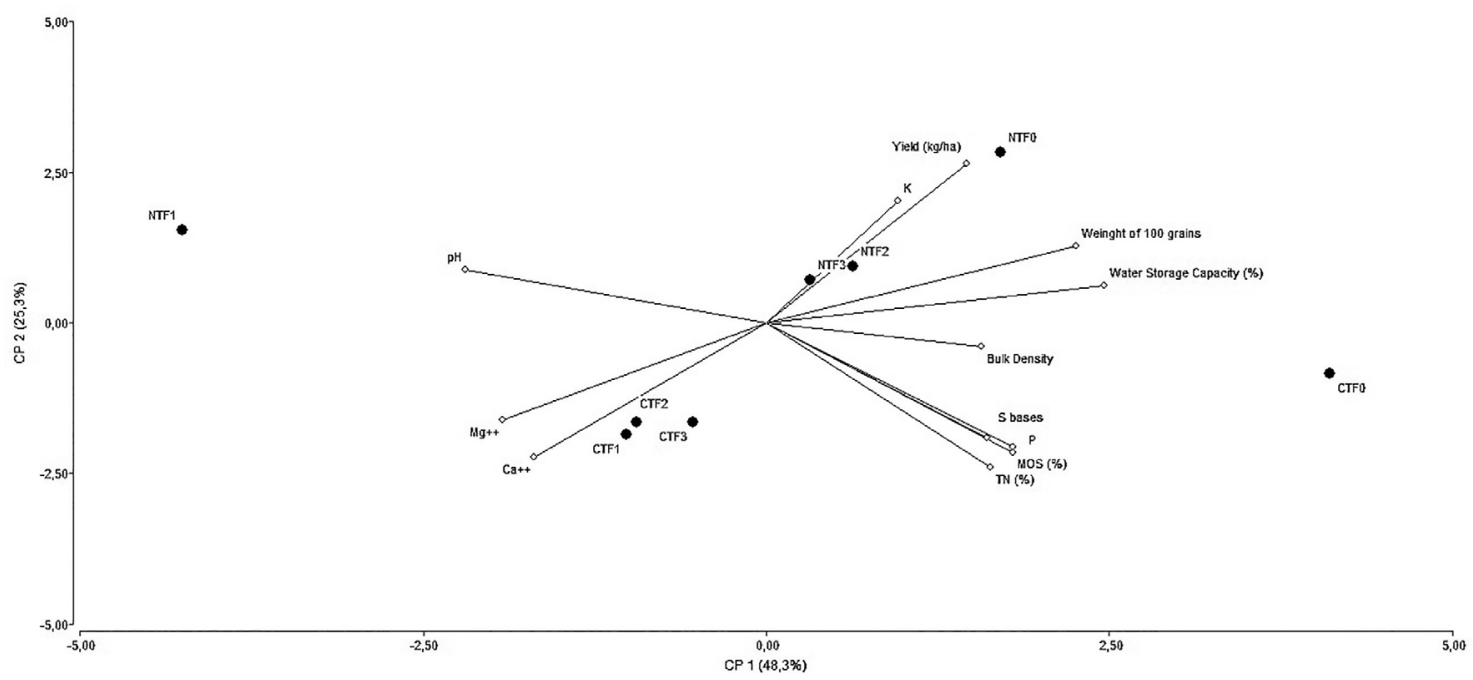

Fig. 1. Grouping of the main chemical and physical variables as effect of tillage, and $\mathrm{N}$ rates after the first cycle of beans of two crop rotation schemes. CTF = conventional till $\mathrm{N}$ rate; NTF no-till $\mathrm{N}$ rate.

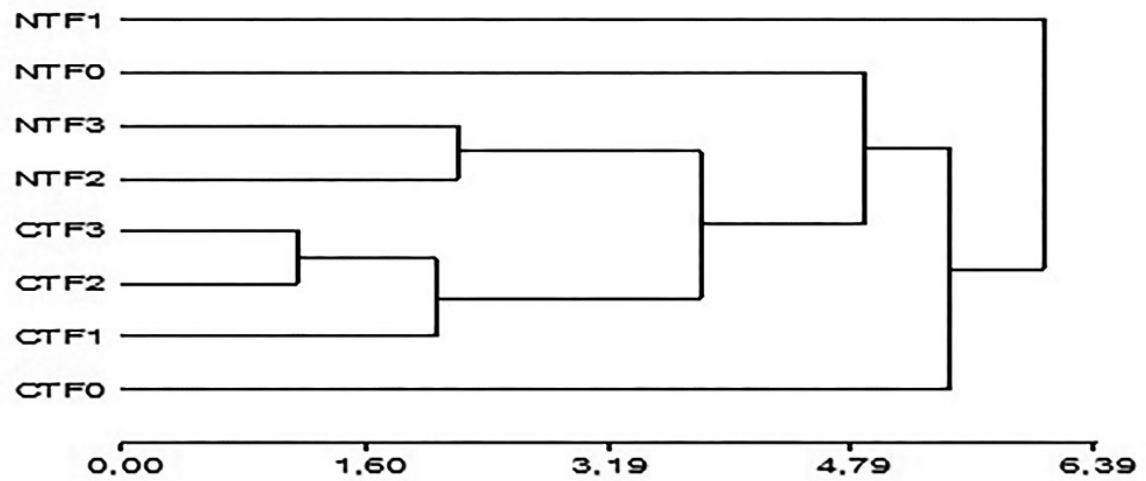

Fig. 2. Analysis of non-hierarchical conglomerates of experimental units considering all response variables studied for two tillage systems and nitrogen rates after the first cycle of beans of two crop rotation schemes. $\mathrm{CTF}=$ conventional till $\mathrm{N}$ rate; $\mathrm{NTF}$ no till $\mathrm{N}$ rate.

compared to that obtained with conventional tillage (CT). This suggest that NT allows for a more adequate set of soil physical and chemical characteristics, leading to better crop yields. There was a significant difference in favor of NT in the $0-5 \mathrm{~cm}$ soil layer in terms of water storage capacity, $\mathrm{pH}$, soil $\mathrm{P}$ and $\mathrm{K}$. In spite of the lack of significance for SOM and TN, the trend of higher values for NT is evident, indicating that no soil disturbance improves soil conditions for plant growth even when no fertilizers are applied.

\section{ACKNOWLEDGEMENTS}

Special thanks to professors, lab technicians, and undergraduate students from UCE for their comments, help, and interest during the field and lab activities.

Funding Information: The present study was financed by the UCE - UFRO 2014-2019 cooperation agreement for Doctoral Studies. Montesdeoca F. and Avila-Salem were supported by the UCE Doctoral Scholarship Grant N 304.

\section{LITERATURE CITED}

Allison, L. 1979. Organic carbon. In C. Black, D. Evans, J. White, L. Ensminger and F. Clark (eds.). Methods of soil analysis. Part 2. p. 1367-1378. American Society of Agronomy. Wisconsin, USA. 
Alvarado, S., R. Jaramillo, F. Valverde, and R. Parra. 2011. Manejo de nutrientes por sitio específico en el cultivo de maíz bajo labranza de conservación para la provincia de Bolívar. INIAP-IPNI, Quito, Ecuador.

Alvarez, C., M. Taboada, F. Gutierrez, A. Bono, P. Fernandez, and P. Prystupa. 2009. Topsoil properties as affected by tillage systems in the Rolling Pampa region of Argentina. Soil Science Society of America Journal 73:12421250.

Avila-Salem, M., F. Montesdeoca, M. Orellana, K. Pacheco, S. Alvarado, N. Becerra, et al. 2020. Soil biological properties and arbuscular mycorrhizal fungal communities of representative crops established in the Andean region from Ecuadorian highlands. J. Soil Sci. Plant Nutr. doi.org/10.1007/s42729020-00283-1

Balota, E.L., A. Colozzi Filho, D.S. Andrade, and R.P. Dick. 2004. Long-term tillage and crop rotation effects on microbial biomass and $\mathrm{C}$ and $\mathrm{N}$ mineralization in a Brazilian Oxisol. Soil and Tillage Research 77:137-145.

Basanta, M., C. Cesaretti, E. Lovera and M. Ghiotti. 2012. Efecto de labranzas sobre fracciones de carbono en una experiencia de larga duración. Acta en CD. In C. Videla (ed.). XIX Congreso Latinoamericano y XXIII Congreso Argentino de la Ciencia del Suelo "Latinoamérica unida protegiendo sus suelos". Asociación Argentina de la Ciencia del Suelo, Mar de Plata, Argentina.

Blake, G. 1976. Bulk density. In C. Black, D. Evans, J. White, L. Ensminger and F. Clark (eds.). Methods of Soil Analysis. Part 1. p. 374-391. American Society of Agronomy. Madison, Wisconsin, USA.

Blanco-Canqui, H., L. Stone, A. Schlegel, D. Lyon, M. Vigil, M. Mikha, et al. 2009. No-till induced increase in organic carbon reduces maximum bulk density of soils. Soil Science Society of America Journal 73:1871-1879.

Blanco Canqui, H. 2012. Soil management for sustainable production with emphasis on erosion control and modeling. p.1-6. In C. Videla (ed.). XIX Congreso Latinoamericano y XXIII Congreso Argentino de la Ciencia del Suelo "Latinoamérica unida protegiendo sus suelos". Asociación Argentina de la Ciencia del Suelo, Mar de Plata, Argentina.

Blanco-Moure, N., A. Bielsa, R. Gracia, and M. López. 2011. Long-term effect of no-tillage on soil organic matter fractions in rainfed Aragon (NE Spain). Spanish Journal of Soil Science 1:116-121.
Bloom, P., and U. Skyllberg. 2012. Soil pH and pH buffering. p. 19-11 - 19-14. In P. Huan, Y. Li and M. Summer (eds.). Handbook of Soil Sciences. CRC Press, Boca Raton, Florida, USA.

Bremner, J. 1979. Total nitrogen. In C. Black, D. Evans, J. White, L. Ensminger and F. Clark (eds.). Methods of soil analysis. Part 2. p. 1149-1176. American Society of Agronomy. Wisconsin, USA.

Bronick, C., and R. Lal. 2005. Soil structure and management: a review. Geoderma 124:3-22.

Crovetto, C. 2006. No-tillage: The relationship between no tillage, crop residues, plants and soil nutrition. Therma Impresores S.A., Hualpén, Chile.

de Moraes, M., H. Debiasi, R. Carlesso, J. Franchini, V. da Silva, and F. da Luz. 2015. Soil physical quality on tillage and cropping systems after two decades in the subtropical region of Brazil. Soil and Tillage Research 155:351-362.

Derpsch, R., T. Friedrich, A. Kassam, and H. Li. 2010. Current status of adoption of no-till farming in the world and some of its main benefits. International Journal of Agricultural and Biological Engineering 3:1-25.

Dexter, A. 2004. Soil physical quality: Part I. Theory, effects of soil texture, density, and organic matter, and effects on root growth. Geoderma 120:201-214.

Di Rienzo, J., F. Casanoves, M. Balzarini, L. Gonzalez, M. Tablada, and C. Robledo. 2018. InfoStat version 2018. Centro de Transferencia InfoStat, FCA, Universidad Nacional de Córdoba, Córdoba, Argentina.

Díaz-Zorita, M., M. Barraco, and C. Alvarez. 2004. Efectos de doce años de labranzas en un Hapludol del Noroeste de Buenos Aires, Argentina. Ciencia del Suelo 22:11-18.

Espinosa, J., and J. Moreno. 2018. Land management. p. 151-163. In J. Espinosa, J. Moreno and G. Bernal (eds.). Soils of Ecuador. Springer, Gewerbestrasse, Switzerland.

Gallager, R., R. Stehouwer, V. Barrera, S. Alvarado, L. Escudero, F. Valverde, et al. 2017. Yield and nutrient removal in potato-based conservation agriculture cropping systems in the high altitude Andean region of Ecuador. Agronomy, Soils \& Environmental Quality 109:1-13.

Gardner, W. 1976. Water content. In A. Black, D. Evans, J. White, L. Ensminger and F. Clark (eds.). Method of Soil Analysis. Part 1. American Society of Agronomy, Madison, Wisconsin, USA.

Grove, J., R. Ward, and R. Weil. 2007. Nutrient stratification in no-till soils. Agron. J 65:781783. 
Havlin, J., J. Beaton, S. Tisdale, and W. Nelson. 2014. Soil fertility and fertilizers: An introduction to nutrient management. $8^{\text {th }}$. ed. Pearson Education, Prentice Hall, USA.

Heald, W. 1979. Calcium and magnesium. p. 999-1009. In C. Black, D. Evans, J. White, L. Ensminger and F. Clark (eds.). Methods of soil analysis. Part 2. American Society of Agronomy, Wisconsin, USA.

Jat, H., A. Datta, M. Choudhary, A. Yadav, V. Choudhary, P. Sharma, et al. 2019. Effects of tillage, crop establishment and diversification on soil organic carbon, aggregation, aggregate associated carbon and productivity in cereal systems of semi-arid Northwest India. Soil and Tillage Research 190:128-138.

Khan, S., A. Shah, M. Nawaz, and M. Khan. 2017. Impact of different tillage practices on soil physical properties, nitrate leaching and yield attributes of maize (Zea mays L.). Journal of Soil Science and Plant Nutrition 17:240-252.

Lal, R. 2015. Restoring soil quality to mitigate soil degradation. Sustainability 7:5875-5895.

Li, H., H. Gao, H. Wu, W. Li, X. Wang, and J. He. 2007. Effects of 15 years of conservation tillage on soil structure and productivity of wheat cultivation in northern China. Aust. J. Soil Res. 45:344-350.

Lupwayi, N., G. Clayton, J. O'Donovan, K. Harker, T. Turkington, and Y. Soon. 2006. Soil nutrient stratification and uptake by wheat after seven years of conventional and zero tillage in the Northern Grain belt of Canada. Canadian Journal of Soil Science 86:767-778.

Moreno, J., F. Yerovi, M. Herrera, D. Sánchez, and J. Espinosa. 2018. Soils from the Ecuadorian highlands. In J. Espinosa, J. Moreno and G. Bernal (eds.). Soils of Ecuador. Springer, Cham, Switzerland.

Morison, J., N. Baker, P. Mullineaux, and W. Davies. 2008. Improving water use in crop production. Philosophical Transactions of the Royal Society B: Biological Sciences 363:639658.

Munkholm, L., R. Heck, and B. Deen. 2013. Long-term rotation and tillage effects on soil structure and crop yield. Soil and Tillage Research 127:85-91.

Peech, M. 1979. Hydrogen-ion activity. In A. Black, D. Evans, J. White, L. Ensminger and C. Clark (eds.). Methods of Soil Analysis. Part 2. p. 914-925. American Society of Agronomy, Madison, Wisconsin, USA.

Pratt, P. 1979. Potassium. In C. Black, D. Evans, J. White, L. Ensminger and F. Clark (eds.). Methods of soil analysis. Part 2. p. 1022-1030. American Society of Agronomy, Madison, Wisconsin, USA.
Quichimbo, P., G. Tenorio, P. Borja, I. Cárdenas, P. Crespo, and R. Célleri. 2012. Efectos sobre las propiedades físicas y químicas de los suelos por el cambio de la cobertura vegetal y uso del suelo: páramo de Quimsacocha al sur del Ecuador. Suelos Ecuatoriales 42:138-153.

Rahman, M., A. Okubo, S. Sugiyama and H. Mayland. 2008. Physical, chemical and microbiological properties of an Andisol as related to land use and tillage practice. Soil and Tillage Research 101:10-19.

Raphael, J., J. Calonego, D.M. Milori, and C. Rosolem. 2016. Soil organic matter in crop rotations under no-till. Soil and Tillage Research 155:45-53.

Roldan, A., J. Salinas-Garcia, M. Alguacil, and F. Caravaca. 2007. Soil sustainability indicators following conservation tillage practices under subtropical maize and bean crops. Soil and Tillage Research 93:273-282.

Sainju, U., B. Singh, and W. Whitehead. 2005. Tillage, cover crops, and nitrogen fertilization effects on cotton and sorghum root biomass, carbon, and nitrogen. Agronomy Journal 97:1279-1290.

Sims, J. 2000. Soil test phosphorus: Olsen P. In G. Pierzynsky (ed.) Methods of phosphorus analysis for soils, sediments, residuals, and waters. 20 p. North Caroline State University, Raleigh, USA.

Singh, A., V. Phogat, R. Dahiya, and S. Batra. 2014. Impact of long-term zero till wheat on soil physical properties and wheat productivity under rice-wheat cropping system. Soil and Tillage Research 140:98-105.

Tormena, C., D. Karlen, S. Logsdon, and M. Cherubin. 2017. Corn stover harvest and tillage impacts on near-surface soil physical quality. Soil and Tillage Research 166:122-130.

Vidal, I., J. Etchevers, and A. Fischer. 2002. Dinámica del nitrógeno bajo diferentes rotaciones, sistemas de labranza y manejo de residuos en el cultivo de trigo. Agricultura Técnica 62:121-132.

Wingeyer, A., T. Amado, M. Pérez-Bidegain, G. Studdert, C. Perdomo, F. Garcia, et al. 2015. Soil quality impacts of current South American agricultural practices. Sustainability 7:22132242.

Zotarelli, L., N. Zatorre, R. Boddey, S. Urquiaga, C. Jantalia, J. Franchini, et al. 2012. Influence of no-tillage and frequency of a green manure legume in crop rotations for balancing $\mathrm{N}$ outputs and preserving soil organic $\mathrm{C}$ stocks. Field Crops Research 132:185-195. 